\title{
The Sensitivity of European Bank Stocks to German Interest Rates Changes
}

\author{
Simon Stevenson \\ University College Dublin, Ireland
}

\begin{abstract}
This study examines the cross-border impact of central bank interest rate changes, using the example of the German Bundesbank. We examine the price impact of rate changes on both the general stock markets and on bank stocks in seven other European countries. The sample includes nations both within and outside of the European Union, and includes EU members who are participating in monetary union and members who obtained opt-outs. The results point to the existence of cross-border information transfers. Both nonGerman bank stocks and general equities react significantly to a large number of the Bundesbank rate changes. The results also indicate that European capital markets did differentiate between rate changes in terms of their relative importance. This was the case in terms of different responses between the financial institutions and the general equity markets and with regard to differing reactions between markets. In particular, those markets that were more committed to the exchange rate mechanism and the goal of monetary union generally reacted more than markets such as Denmark and UK. In addition, the importance of Bundesbank policy during the years leading up to EMU is supported by the fact that most non-German bank stocks reacted more to Bundesbank policy than to domestic rate changes and that no other country had the same level of influence on foreign equity returns (JEL E44, E58, F33, G15, G21).
\end{abstract}

Keywords: bank interest rate sensitivity, cross-border information transfers.

\section{Introduction}

Numerous studies have examined the price impact of central bank policy changes on bank stocks; however, this article takes a very specific view.

*The author would like to extend his appreciation to three anonymous referees and the editor for comments on an earlier draft of this article which have greatly improved the article.

(Multinational Finance Journal, 2002, vol. 6, no. 3\&4, pp. 223-249)

(CMultinational Finance Society, a nonprofit corporation. All rights reserved.

DOI: $10.17578 / 6-3 / 4-4$ 
We examine the impact of German interest rate changes over the period 1987 to 1998 on banks and general equity markets in seven other European countries. The seven markets examined include four who are subsequently participating in monetary union (France, Italy, the Netherlands and Spain), two EU countries who have opted-out of the single currency (Denmark and UK) and one who is outside of the EU, but significantly linked with the German economy (Switzerland). This study is therefore partly a retrospective examination of a pre-single currency environment and partly an assessment of the possible impact on European banks outside of the Euro-zone following monetary union. In order to assess whether non-German European bank stocks and equity markets display significant price reactions to Bundesbank policy, a total of 29 interest rate changes are examined. The results firstly allow an analysis of whether changes in German monetary policy had a crossborder impact, and secondly, whether that impact differed between the seven countries, depending on their relationship with Germany and their future participation in the single currency. We also examine the reaction to domestic rate changes in the context of controlling for information already available in the markets. In addition, the focus of the article with regard to the dissemination of information, also allows comparison with studies that have examined the inter-relationships between European equity markets. The rationale behind the examination of both bank stocks specifically and the general equity markets centers around the fact that due to events such as the ERM crisis, Bundesbank rate changes had a wider impact than purely on financial institutions. The remainder of the article is organized as follows: Firstly, a brief review of the existing literature and empirical evidence is presented, while the data requirements are then discussed. The following three sections report the empirical results, while the final section provides concluding comments.

\section{Existing Empirical Evidence}

The literature available on the price of new information in the financial markets is vast, with large numbers of empirical studies to have examined the price impact of various events. Studies have examined issues ranging from earnings announcements (Ball and Brown, [1968]), 
default announcements (Karafiath et al., [1991]) and bankruptcy announcements (Lang and Stultz, [1992]) to celebrity endorsements (Agrawal and Kamukara, [1995]) and nuclear accidents (Bowen et al. [1983]). Of particular relevance to the current study are those articles that have explicitly examined the price impact of macro-economic information and specifically interest rate changes. Castanias (1979) focused on the increase in volatility coinciding with the release of US economic information. In addition to interest rate changes by the Federal Reserve, the article also examined items such as consumer price levels and more general economic indicators. The results reveal that with routine announcements there is some evidence of anticipation by the market. Pearce and Roley (1985) extend this analysis to examine the issue of expected and unanticipated news using survey data. The authors find that stocks react significantly to unexpected changes in money supply figures and to changes in the discount rate post 1979. This result is unsurprising as prior to 1979 the Federal Reserve effectively changed the discount rate in response to, and to bring it into line with, market rates. The issue of technical and non-technical rate changes has been the subject of a number of studies which examined the American market. Examples include Roley and Troll (1984), Smirlock and Yawitz (1985), Cook and Haen (1988) and Duecker (1992).

While empirical evidence has found that general equities tend to react significantly to interest rate changes, and in particular to unanticipated changes, the specific example of bank stocks has been less conclusive. Flannery (1983) argues that financial institutions should have sufficient resources to enable them to perpetually hedge against interest rate exposure by matching the duration of their assets and liabilities. This argument therefore implies that long-run profits would remain unaffected by changes in market rates. The author examines reported operating revenue/costs for sixty banks over the period 1960 to 1978. These figures are then regressed on the following variables; (a) lagged revenue divided by lagged total assets, representing the hypothesized market response to changes in market conditions, (b) the current market interest rate, (c) the annual volatility of the rate and (d) the return on assets purchased within the current period. The results suggest that few of the banks carried significant mismatches. Those that did exhibited shorter asset maturities than liability maturities, 
contrary to the traditional expectation that banks borrow short and lend long. The author finds that when maturity mismatches and immediate effects are calculated together, profit variations are not significant in the long run. Exceptions are those institutions whose margin varies directly with market rates.

Studies that have examined the short-run impact have consistently found bank stocks to be sensitive to rate changes. ${ }^{1}$ Of particular relevance to the current study is Kaen et al. (1997), who examined the price impact of 27 Bundesbank rate changes between 1985 and 1993 on both German bank stocks and the FAZ General Equity Index. As with the American empirical evidence, the authors find that for both the overall market and for the bank sector, there is a significant negative relationship between rate movements and share price reaction. In addition, the study uses changes in the Repo rate as an indicator of whether the rate change was anticipated by the market. The analysis of the results concerned with rate changes when no such Repo signal occurred supports the empirical evidence from the United States with regard to technical and non-technical rate changes. Due to the fact that the time period examined included the 1992-1993 currency crisis, and that the Bundesbank came under political pressure to reduce rates, Kaen et al. (1997) specifically examines the downward movements in rates during this period. The authors propose the hypothesis that due to the political background the markets may have reacted negatively to rate decreases during this period. The results do not however support the premise that the markets viewed these interest rate cuts as an indication that the Bundesbank's resolve concerning inflation was weakening.

In addition to the literature that has analyzed discount rate changes, there is a large literature to have examined the impact of market interest rates on security prices. While consistent evidence is to some degree lacking in earlier studies, articles such as Sweeny and Warga (1986) do find evidence to support the hypothesis that certain types of firms, such as banks, are sensitive to interest rate movements and that interest rate risk is priced. ${ }^{2}$ More recent studies have utilized time-varying models to

1. Examples of such studies include Flannery and James (1984) and Choi, Elyasiani and Kopecky (1992).

2. Other examples of studies to have examined this issue include Stone (1974), Lynge and Zumwalt (1980), Scott and Peterson (1986) and Bae (1990). 
allow for variability in the sensitivity of security prices to systematic risk factors. Kane and Unal (1988) find that the sensitivity of bank stocks to interest rate changes is time varying, results confirmed by Yourougou (1990) who compares and contrasts periods of relative interest rate stability and volatility. The study finds that during periods of relative stability neither banks or industrial firms display significant sensitivity to interest rate changes. However, the bank stocks do react significantly during periods of relative volatility. Further studies to have examined this issue include, Kwan (1991) who reports that bank stocks are influenced by unanticipated shocks in interest rates, and Choi et al. (1992) and Westmore and Brock (1994) who both extend the existing literature by incorporating foreign exchange rate exposure into their analysis.

A number of recent articles have utilized ARCH based models in an attempt to capture the time-varying nature of the sensitivity of bank stocks to market rates. Song (1994) finds that both the market and interest rate risks of banks do significantly vary, findings supported by Flannery et al. (1997), who also report that conditional interest rate volatility is a significant influence. Elyasiani and Mansur (1998) utilized a GARCH-M model on a sample of monthly returns for 56 US banks. The results show that both the levels and volatility of interest rates significantly impact on the first and second moments of bank stocks. ${ }^{3}$

While this study is primarily concerned with the potential price impact of interest rate changes by the Bundesbank, due to the use of a nonGerman sample of firms the results are also of interest in the context of the literature to have examined the relative integration of European equity markets. A growing number of studies have examined the relationships between different European markets, particularly in the light of monetary union and the potential impact that this may have on the degree of integration between European capital markets. In general, despite the existence of the single market and more recently the introduction of the Euro, empirical evidence has provided little evidence of common movements or influences. Fraser et al. (1994) and Espitia and Santamaria (1994), both found little evidence of common movements, the results supporting the findings of Eun and Shim (1989), finding that American and Japanese factors were more influential than

3. See also Neuberger (1994). 
European factors. These results also aid weight to those studies that have assessed the relative importance of national and industrial factors across European stocks. Articles such as Drummen and Zimmermann (1992) and Rouwenhorst (1999) have found that country specific factors dominate. Any evidence in favor of the hypothesis of co-movement between European markets has tended to be have utilized causality or GARCH based tests. Kanas (1998) analyzed the Frankfurt, London and Paris bourses using daily data over the period 1984 to 1994. Employing an Exponential GARCH model the author found reciprocal volatility spillovers between London and Paris and between Paris and Frankfurt, and uni-directional; spillovers from London to Frankfurt. In addition, the results indicate that the spillovers have become more prominent in more recent years.

\section{Data Requirements}

The primary rates under the German monetary system were the Discount and Lombard rates. The discount rate was the lowest rate at which the Bundesbank lent to the German banking sector and was viewed as a permanent source of financing. The Lombard rate was more similar to the mechanisms available in markets such as the United States, as it was an emergency facility. In addition to the two primary rates the Bundesbank also used repurchase agreements. Due to the use of the repo rate this article examines whether movements in the repo rate had a significant impact on the price reaction to changes in either of the two primary rates. In total 29 German rate changes are examined in this article, with the last taking place in April 1996. Out of the 29 rate changes, on eighteen occasions both the Discount and Lombard rates were changed, while in the remaining eleven cases, seven saw the discount rate altered, with four separate Lombard rate movements. Table 1 and figure 1 report the changes in the two rates and state whether there was a change in the repo rate during the week prior to the Discount or Lombard rate change.

In addition to the primary analysis of non-German banks, this study also examines the general equity markets in each of the seven markets, and for comparative purposes, re-examines the price reaction of German 
TABLE 1. Bundesbank Rate Changes, 1987-1998

\begin{tabular}{|c|c|c|c|}
\hline Event Date & Discount Rate & Lombard Rate & Repo change \\
\hline \multicolumn{4}{|l|}{ (from prior week) } \\
\hline December 4, 1987 & 2.5 & 4.5 & No Change \\
\hline July 1,1988 & 3 & 4.5 & 0.25 \\
\hline July 29, 1988 & 3 & 5 & 0.25 \\
\hline August 26, 1988 & 3.5 & 5 & No Change \\
\hline December 16, 1988 & 3.5 & 5.5 & 0.65 \\
\hline January 20, 1989 & 4 & 6 & No Change \\
\hline April 21, 1989 & 4.5 & 6.5 & 0.35 \\
\hline June 30, 1989 & 5 & 7 & -0.05 \\
\hline October 6, 1989 & 6 & 8 & 0.475 \\
\hline November 2, 1990 & 6 & 8.5 & 0.025 \\
\hline February 1, 1991 & 6.5 & 9 & No Change \\
\hline August 16, 1991 & 7.5 & 9.25 & 0.10 \\
\hline December 20, 1991 & 8 & 9.75 & No Change \\
\hline July 17, 1992 & 8.75 & 9.75 & No Change \\
\hline September 14, 1992 & 8.25 & 9.5 & No Change \\
\hline February 5, 1993 & 8 & 9 & -0.01 \\
\hline March 19, 1993 & 7.5 & 9 & No Change \\
\hline April 23, 1993 & 7.25 & 8.5 & -0.02 \\
\hline July 2, 1993 & 6.75 & 8.25 & -0.01 \\
\hline July 30, 1993 & 6.75 & 7.75 & -0.20 \\
\hline September 10, 1993 & 6.25 & 7.25 & No Change \\
\hline October 22, 1993 & 5.75 & 6.75 & No Change \\
\hline February 18, 1994 & 5.25 & 6.75 & No Change \\
\hline April 15, 1994 & 5 & 6.5 & -0.03 \\
\hline May 13, 1994 & 4.5 & 6 & -0.06 \\
\hline March 31, 1995 & 4 & 6 & No Change \\
\hline August 25, 1995 & 3.5 & 5.5 & -0.06 \\
\hline December 14, 1995 & 3 & 5 & No Change \\
\hline April 18, 1996 & 2.5 & 4.5 & No Change \\
\hline
\end{tabular}

banks and general equities to the same events. The rationale behind examining the general equity markets is that due to the period examined, and in particular the inclusion of the ERM crisis of 1992 and 1993 in the sample period, the importance of Bundesbank rate changes was of such a magnitude that it is likely that overall equity markets were affected as well as bank stocks. 


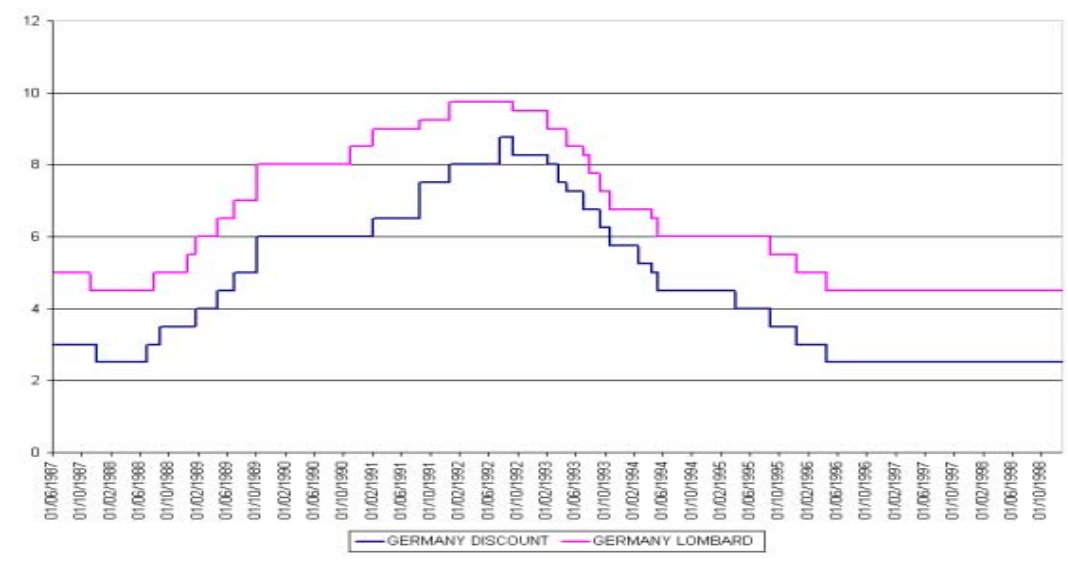

FIGURE 1.-Bundesbank Discount \& Lombard Interest Rate Changes

We analyze the reaction of a total of 37 banks, with a minimum of three institutions in each market. The criteria for inclusion was that the banks were of a relatively large capitalization, were actively traded with price changes observed on each trading day and were continuously traded throughout the analysis. While this criteria may lead to the potential for survivorship bias, it can be argued that the use of well established large capitalization banks provides an opportunity to examine those institutions that have substantial international operations and are therefore perhaps more likely to be influenced by changes in Bundesbank policy. It should likewise be noted though that the use of such a sample might perhaps lead to the results not being representative for smaller more localized banks and that the results may overstate the general impact on all financial institutions. For the general equity indices, we analyze the primary equity market in each country, except in the case where such an index was unavailable for the whole sample period. In such cases we use the Datastream Market Index for that market. ${ }^{4}$

\section{Response of General Equity Markets}

The first series of empirical tests examine to what degree the general equity indices under consideration were affected by movements in

4. Table A1 in the appendix details all of the banks and indices used in this study. 
German interest rates. The tests consist of OLS regressions of the following form for each of the seven markets, in addition to the domestic German market.

$$
\begin{aligned}
& R E_{i, t}=\alpha_{i}+\beta_{1}(D U)+\beta_{2}(D D)+\beta_{3}(L U) \\
& +\beta_{4}(L D)+\beta_{5}(D L U)+\beta_{6}(L D U)+\varepsilon_{i},
\end{aligned}
$$

where $R E$ is the daily return on the equity index, $D U$ is a dummy variable indicating that the discount rate was increased, $D D$ indicates that the discount rate was reduced, $L U$ and $L D$ are corresponding dummy's for the Lombard rate, while $D L U$ represents dates when both rates rose and $D L D$ indicates that both rates were reduced. The dummy variables were used in relation to a two-day event window around each announcement. The two days include the date the rate change came into effect, and the day prior to this. This stance was adopted as the Bundesbank may have announced the rate change prior to the close of markets, with the rate change coming into effect the following day. It would be expected that when rates fall stock prices would see a positive response and vice-versa.

Table 2 reports the results from equation 1, with the results showing that very few of the coefficients are statistically significant at conventional levels. The results for the German equity market are broadly in line with those reported by Kaen et al. (1997), with the German market reacting significantly, and with the anticipated sign, to changes in the discount rate only and for those event dates when both the discount and Lombard rates are changed. However, as with the Kaen et al. (1997) study, the market does not react to the same degree when only the Lombard rate is changed. In the previous study a significant result was obtained when the Lombard rate was reduced, while in this article the reverse is true. It should however be noted that there were only four occasions on which only the Lombard rate was altered, out of a total of 29 rate changes. The results with regard to the other European markets see only six significant coefficients out a total of 42, however all six coefficients are of the expected sign. The Spanish market sees significant negative responses to increases in the discount rate and when both rates are increased. In addition the Dutch reacts significantly to discount rate rises, while UK market responds to 


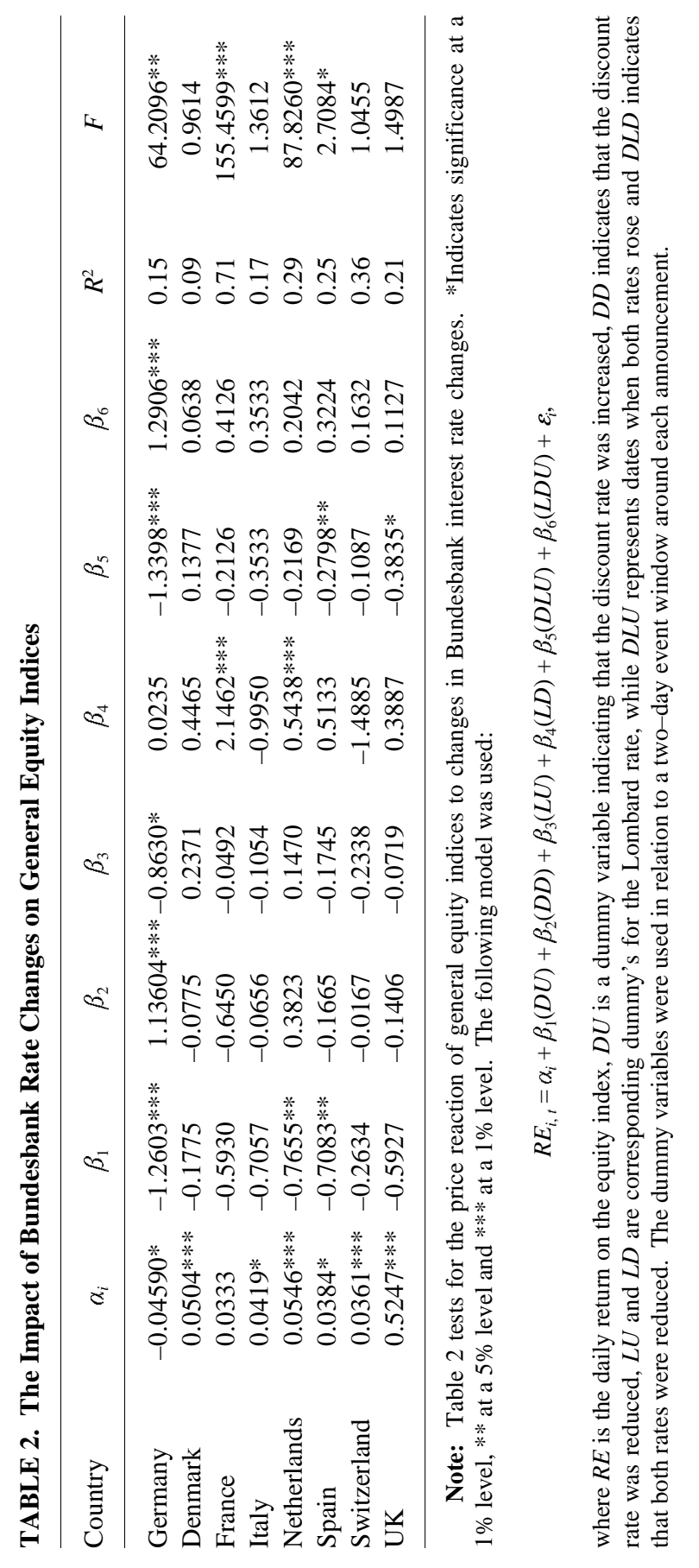


combined increases in the two rates. It is perhaps surprising that two of the markets react significantly to reductions in the Lombard rate, France and the Netherlands, when neither reacts in a similar manner to reductions in the discount rate or when both rates fall simultaneously. Again, the small number of Lombard only rate changes may be a factor in these findings. It is noticeable that the three markets that produce a statistically significant $F$-statistic are those who were the most stable members of the ERM, namely France, the Netherlands and to a lesser extent Spain. It is however perhaps surprising that despite the inclusion of the ERM crisis period in the sample, none of the seven markets significantly react to events when the discount rate is reduced. For comparative purposes we run a similar regression for each markets domestic rate changes.

$$
R E_{i, t}=\alpha_{i}+\beta_{1}(D U)+\beta_{2}(D D)+\varepsilon_{i},
$$

where $D U$ is a dummy variable indicating that the domestic rate was increased and $D D$ indicates that the rate was reduced. As with the Bundesbank rate changes a similar two-day event window is used. The results are reported in table 3 and it is evident that there are very few significant results in comparison to both the German results reported previously and in previous studies from markets such as the United States. Out of a total of 14 coefficients, seven are significant, however all are of the correct sign. It is of interest that the Dutch equity market does not respond significantly to changes in the domestic discount rate. This is perhaps due to the fact that the Netherlands was the strongest member of the ERM with Germany, and looked more towards German rate changes, a hypothesis supported by the results already discussed. In addition, the mixed results from the other markets would also suggest some use of the Bundesbank rate changes by the market for informational purposes.

In order to more closely examine the price reaction to specific event dates we also examine the price impact through the use of cumulative abnormal returns. We define the normal return for equities as the average daily return over an estimation period of 200 days, starting 15 days prior to the rate change. In the case of rate changes occurring close together, the 30-day period around each rate change is excluded for the purposes of calculating the normal returns. The two-day $C A R \mathrm{~s}$ 
TABLE 3. The Impact of Domestic Rate Changes on General Equity Indices

\begin{tabular}{llll}
\hline Country & \multicolumn{1}{c}{$\alpha_{i}$} & \multicolumn{1}{c}{$\beta_{1}$} & $\beta_{2}$ \\
\hline Denmark & $0.0404 * * *$ & $-0.3950 * *$ & 0.0120 \\
France & 0.0328 & -0.3176 & $0.2239 *$ \\
Italy & 0.0201 & $-0.8463 * * *$ & $0.5227 * * *$ \\
Netherlands & $0.0507 * * *$ & -0.3133 & -0.0010 \\
Spain & $0.0447 * *$ & $-0.4842^{* *}$ & 0.1559 \\
Switzerland & -0.1987 & $-0.2801 *$ & $0.1998^{* *}$ \\
UK & $0.0348^{* *}$ & $-0.2999 * *$ & -0.0317 \\
\hline
\end{tabular}

Note: Table 3 tests for the price reaction of general equity indices to changes in each markets domestic interest rate. *Indicates significance at a $1 \%$ level, ** at a 5\% level and *** at a $1 \%$ level. The following model was used:

$$
R E_{i, t}=\alpha_{i}+\beta_{1}(D U)+\beta_{2}(D D)+\omega i
$$

where $R E$ is the daily return on the equity index, $D U$ is a dummy variable indicating that the rate was increased and $D D$ indicates that the discount rate was reduced. The dummy variables were used in relation to a two-day event window around each announcement.

are tested for significance using the following $t$-statistic.

$$
t=\frac{C A R}{S E \sqrt{k}}
$$

where $k$ is the number of observations in the event period and $S E$ is the standard error of the $C A R$, which can be defined as:

$$
S E=\sqrt{\left[\frac{1}{200} \sum_{T-15}^{T-214}\left(R_{t}-\bar{R}_{t}\right)^{2}\right]} .
$$

As with the OLS tests, the empirical findings reported in table 4 would suggest that while the movement of German interest rates did not have a consistently significant impact on stocks in other European markets, there are a relatively large number of significant results. In addition, across the seven markets the number of significant responses do not tend to differ substantially from that in Germany itself. German stocks significantly responded on 10 occasions, however, three of these CARs 


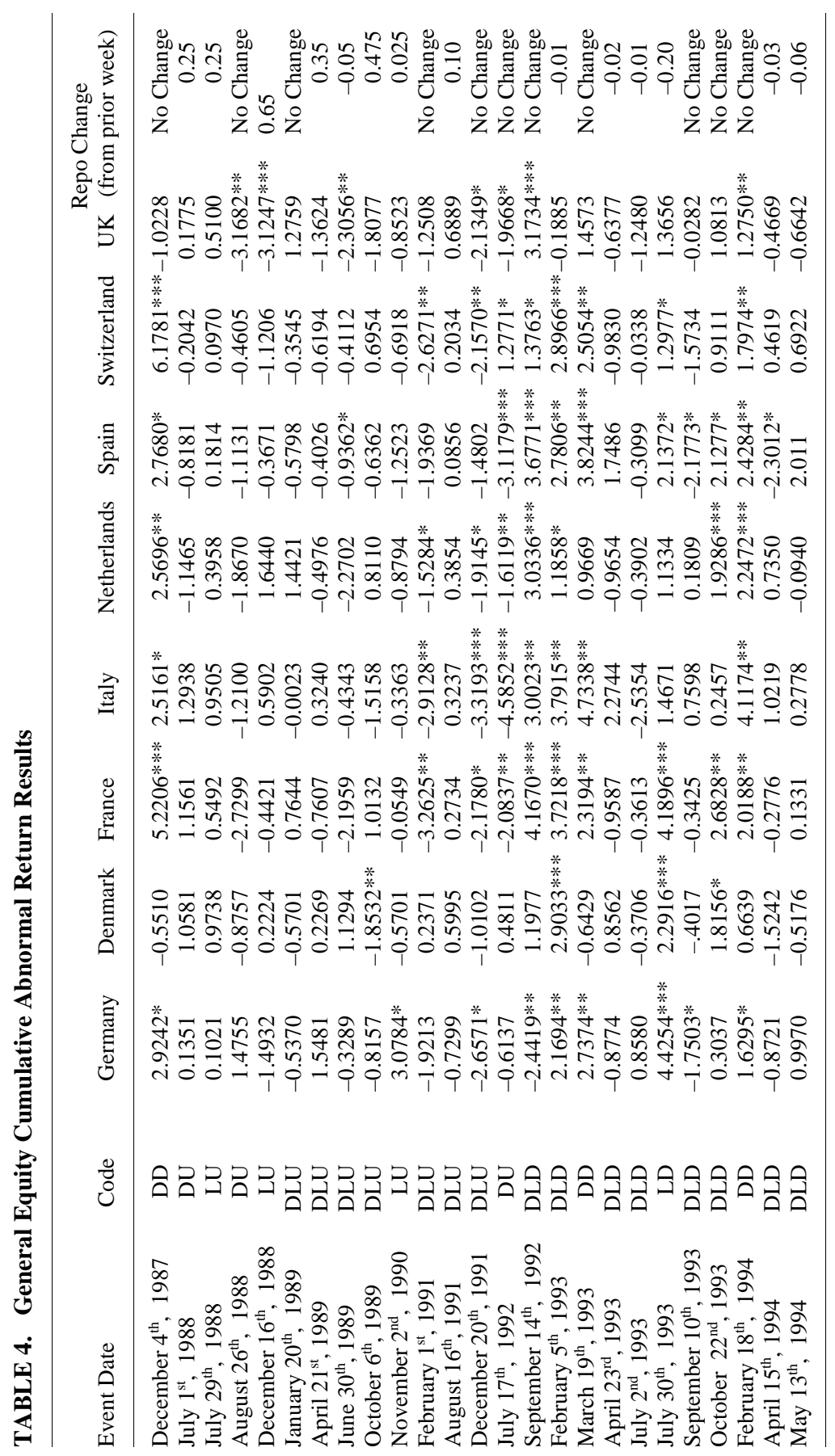




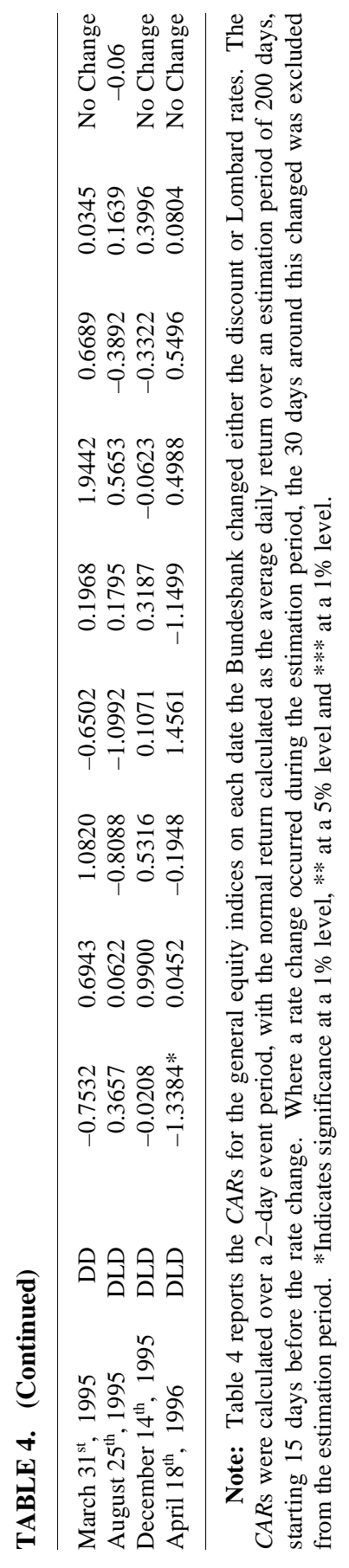


were of the 'wrong' sign. Of the remaining markets a total of 57 significant results were found, out of a possible total of 203 events. What is of greater note is that 54 of the 57 significant $C A R$ s were of the anticipated sign. The results do tend to support the hypothesis that the non-German markets were selective in terms of the rate changes to which they responded to and that the response differed across markets. As would be expected a large number of the significant findings are clustered around the ERM crisis of 1992-1993 and other key events. One example is the first event date examined, December 4, 1987, which was just after the October 1987 crash. Of the eight markets analyzed, only Denmark and UK did not report significantly positive $C A R$ s for this date. With regard to the ERM crisis, a total of 26 significant $C A R$ s are reported for the other European markets, in addition to four for the German market itself, with only one of the 30 seeing a response in the 'incorrect' direction.

It is also apparent that different markets responded significantly at different stages of the crisis, the most obvious case being Britain. The three rate changes prior to and at the time of UK's withdrawal from the Exchange Rate Mechanism are all significant, however, after UK had suspended its membership British stocks do not react significantly to any further change in Bundesbank rates. It of interest however, that Italy did not fit in with this pattern and continued to be affected after the suspension of the Lira's membership. In terms of the general reaction, while hard to generalize these results, it is of interest that Denmark and UK, the two EU members who did not subsequently participate in monetary union, have the fewest number of significant responses, with four and seven significant $C A R$ s respectively. In addition, the period after the ERM crisis sees both countries only significantly react once in the expected direction to German rate changes. In contrast, those member states who remained committed to the Euro continued to see a number of significant responses after the relaxation of the ERM bands. It is of interest that Switzerland while outside of both the ERM and the EU, saw nine significant price responses, with eight being of the expected sign. It would therefore appear that despite the lack of formal links with Germany through the EU, the importance of Germany to the Swiss economy led to market information transfers. 


\section{Response of Bank Stock Portfolios}

The empirical tests on the bank stocks take a similar format to those conducted on the general equity markets. Initially, an equally weighted portfolio of the abnormal returns of the bank stocks in each market is formed, while the following regression is then run on each of the portfolios to assess the price impact on the banks.

$$
R_{j, t}=\alpha_{i}+\beta_{i} R E_{j, t}+\sum_{k=1}^{k} \gamma_{j, k} D_{k, t}+\varepsilon_{t}
$$

where $R_{j, t}$ is the return on the equally weighted portfolios, $R E_{j, t}$ is the return on the respective market index and $D_{k, t}$ is a dummy variable equaling unity during each 2 -day event period and zero otherwise. The bank abnormal returns were calculated on the basis of the general equity market being the normal return. The use of a market model is designed to remove the systematic portion of the returns and thus reduce the variance of abnormal returns, leading to a more accurate estimation. ${ }^{5}$ The use of this type of model is justified on a number of points. The standard assumptions of event methodology are likely to be violated in circumstances such as those analyzed in this study, as the return residuals are unlikely to be identically and independently distributed across firms in the same portfolio due to differing levels of firm specific risk. Therefore, the problem of cross-sectional heteroscedasticity is likely to exist. In addition, there is a strong possibility of correlation between the same day returns of firms within the same industry, leading to potential contemporaneous correlation of residuals. The model used takes account of both these issues in the estimation process, permitting more consistent estimates and more robust inferences. The method employed also aids in counter-acting other methodological problems caused by the presence of clustering. Clustering occurs when several securities have event dates at, or around, the same time, and hence event windows overlap or cluster. While in most event studies this would be quite rare, it is an obvious occurrence in this case, with all of the events being common to all firms. The presence of heteroscedasticity is corrected using the Hansen-White method.

5. See MacKinlay (1997). 
The results of the bank portfolios CARs are contained in table 5 . While it may initially appear that the impact of rate changes is far more influential than on the general stock indices previously examined, this is not as clear when the direction of the price response is taken into account. It would be broadly expected that there is an inverse relationship between rate movements and stock prices, however, it should be stated that this is dependent on the specific position of the bank. As Flannery (1983) argues, if banks are able to hedge interest rate exposure through the matching of the duration of their assets and liabilities, the long-run position of the institution should remain unaffected. Therefore, the inverse relationship between stock prices and interest rates is not as clear as with general equities. However, as this study aims to examine the cross-border impact of German interest rate movements, the analysis is based more on new information to the market rather than a direct impact on the institutions operation.

Out of a total of 203 events 97 coefficients are significant for the non-German bank stocks. However, while 57 do display an inverse relationship, the remaining $38 \mathrm{do}$ not, indicating either that banks were fully hedged against interest rate movements or that the German rate changes did not provide new information for the share price. As with the stock index results, significant coefficients tend to cluster around key events, the prime example being the ERM crisis. In addition, while in the analysis of the non-financial firms there appeared to be a relationship between the response and the status of the country in the ERM, this hypothesis is not as clear with the bank stocks. British banks reacted significantly, and in the expected direction, on the four dates following Sterling's suspension from the exchange rate mechanism, while no significant results were found on these dates for the general UK equity market. It would therefore appear that the results do support the idea that the financial markets did take into account the relevance of the announcement in determining the price response, with the financial institutions remaining exposed to changes in German interest rates despite UK's departure from the ERM and the lack of dependency on German interest rates movements in relation to Britain's exchange rate and interest rate policies.

Other factors that would appear to support the view that information transfers were taking place include the low number of significant responses, especially of the anticipated sign, for markets such as 


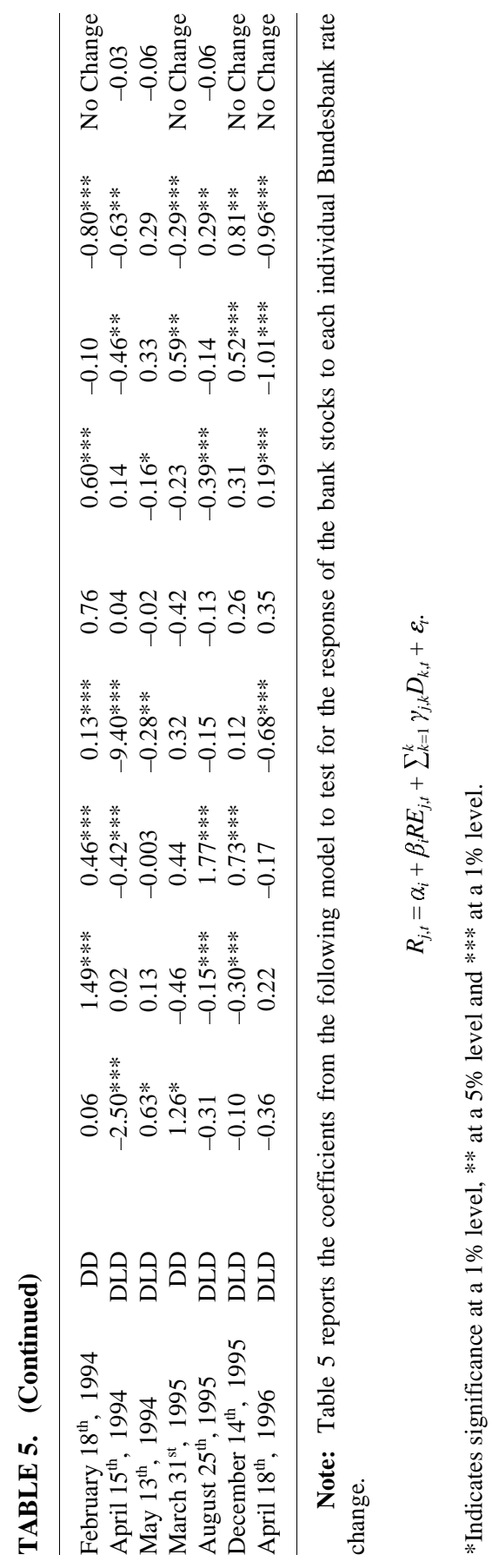


Denmark. While the Danish banks did respond significantly on 11 occasions, only two of these event dates saw the price reaction being in an inverse direction to the interest rate movement. In contrast, the French banking sector saw 14 significant coefficients in the anticipated direction, only slightly behind the figure of 16 for German banks. UK is perhaps slightly unusual in this regard with a high number of significant results, and of those with the expected response, with 14 inverse responses out of a total of 19 total significant coefficients. As with the general equity markets the Swiss market sees a large number of significant results despite not being a member of the EU.

The bank portfolio results also highlight the advantage of analyzing the general equity markets in addition to the financial institutions. On a number of occasions the bank portfolios do not respond significantly to what would have appeared to be key events, however, the general equity markets do see such a response. A prime example of such an occurrence is September 14, 1992, which was one of the key dates during the ERM crisis when UK and Italy suspended their membership of the ERM. Despite the importance of the Bundesbank's reduction of both the Discount and Lombard rates on this date, only German, French and Spanish banks reacted significantly to the news. However, when these results are compared with those for the general equity markets a potential cause becomes apparent. The same interest rate move saw significant positive responses in all of the general equity markets with the exception of Denmark. Due to the use of the general stock markets as the normal return for the bank portfolios, the strong upward movement in the general market by definition reduces the likelihood of obtaining significant results for the bank portfolios. Therefore, what initially appears to be an unusually small number of significant results for the bank portfolios should be viewed in light of the fact that on a number of occasions the general equity market did respond significantly and that movement would reduce the number of significant findings for the banks. ${ }^{6}$

6. Additional tests were also conducted examining the impact of rate changes in the seven non-German markets. These tests examined both the domestic response to rate changes and the response in other European markets. The results are available from the author. The findings show that in the majority of cases there is less evidence of information transfers with domestic rates and other non-German rates in comparison the evidence reported in relation to Bundesbank policy. The only market that sees a similar number of 
TABLE 6. Symmetry of Response to Bundesbank Rate Changes

\begin{tabular}{llcc}
\hline Country & \multicolumn{1}{c}{$\alpha_{i}$} & $\beta_{1}$ & $\beta_{2}$ \\
\hline Germany & $0.8260 * * *$ & 0.0448 & 0.1340 \\
Denmark & $0.3550^{* *}$ & 0.1465 & 0.0833 \\
France & $0.5993 * * *$ & -0.0185 & 0.3490 \\
Italy & $1.2150^{* *}$ & -0.8019 & -0.7983 \\
Netherlands & $0.3930^{* * *}$ & 0.1508 & 0.0770 \\
Spain & $0.2600^{* *}$ & -0.0438 & $0.32667 * *$ \\
Switzerland & $0.4580^{* * *}$ & $-0.2118^{*}$ & -0.1430 \\
UK & $0.6080^{* * *}$ & -0.2088 & 0.2353 \\
\hline
\end{tabular}

Note: Table 6 tests for the symmetry of responses in the bank stocks to Bundesbank rate increases and decreases. We regress the absolute values of the 2-day abnormal returns on a dummy variable that takes the value of unity if the rate was increased. The second dummy variable is used to signify the period around the ERM crisis. The model can be represented as by: $A R_{i, t}=\alpha_{i}+\beta_{1}\left(D_{1}\right)+\beta_{2}\left(D_{2}\right)+\omega i *$ Indicates significance at a $1 \%$ level, *** at a $5 \%$ level and $* * *$ at a $1 \%$ level.

\section{Symmetry of Response}

The final section of the empirical analysis examines whether the reaction of the bank stocks was conditioned in relation to the direction of the change in German interest rate, in effect, whether the response was symmetrical. We use the absolute values of the abnormal returns for each two-day event period and regress them against a dummy variable that takes the value of one if the German rate was increased. We also include a dummy to take account of the ERM crisis. Kaen et al. (1997) performed a similar analysis, finding that German bank stocks did react asymmetrically, with larger responses to interest rate decreases. The analysis, reported in table 6 , provides little evidence of such a result in the context of the current study. Of the eight markets examined, only

significant price reactions in the domestic case is UK. The UK case also highlights the apparent importance of Germany within the ERM, with the majority of significant responses to domestic rate changes occurring either prior to Britain joining the ERM, or following its suspension. The only case where non-German rates appeared to have a significant cross-border impact tended to be on those dates that coincided with a change in German rates. 
Spain sees a significant coefficient, with the finding in line with the results reported by Kaen et al. (1997). Such a response would not be surprising due to the importance of the ERM crisis. It is however, of interest, that in contrast to the Kaen et al. (1997) study, significant findings were not found in relation to the German banks.

In order to test whether the reaction of both the equity markets and the bank stocks was influenced by prior events, we examine the impact of changes in both the German Repo rate and changes in each countries discount rate. In terms of the Repo rate we test whether the markets anticipated changes in the official rate through changes in the Repo rate in the week prior to any of the German Discount or Lombard rate changes. We take the absolute values of the abnormal returns for each two-day event period and regress them against a dummy variable that takes the value of one when there was no change in the Repo rate in the week prior, and zero otherwise. We run similar tests in relation to each markets own discount rate. Two such tests are run. The first model's dummy variable indicates whether the domestic markets discount rate was altered in the week prior to the German rate change, while in the second case we analyze whether Bundesbank rate changes altered expectations with regard to domestic rate changes. This second test may aid in explaining why the non-German markets appear to be more sensitive to German interest rate changes than domestic interest rates.

The results are reported in tables 7 through 9 and reveal that with only one exception none of the coefficients are significant. Table 7 examines whether the response in the bank stocks was conditioned by changes in the Repo in the week prior to the change in either the discount or Lombard rate. In none of the eight cases is the coefficient significant, including the case of Germany, which is contrary to the findings of Kaen et al. (1997). These findings would indicate that investors did not condition their expectations vis-à-vis changes in the repo rate. Table 8 examines the scenario when the Bundesbank altered rates prior to a domestic interest change in the seven other markets. As with the Repo analysis, in none of the cases is the beta coefficient significant. Table 9 reverses the preceding analysis to examine the case where domestic interest rate changes were altered in the week prior to the change in German rates. In this case UK does provide a significant coefficient, indicating that in Britain's case expectations with regard to German rates were influenced by prior changes in UK base rate. 
TABLE 7. Validity of Repo Rate Changes

\begin{tabular}{lcr}
\hline Country & $\beta$ & $T$-Statistic \\
\hline Germany & 0.2089 & 0.6926 \\
Denmark & -0.2291 & -1.3110 \\
France & -0.3018 & -1.3610 \\
Italy & 0.5254 & 0.8299 \\
Netherlands & -0.0522 & -0.3928 \\
Spain & 0.1161 & 0.9731 \\
Switzerland & -0.1080 & -1.0480 \\
UK & -0.1045 & -0.5293 \\
\hline
\end{tabular}

Note: Table 7 tests whether expectations in the response of the bank stocks was conditioned by changes in the German repo rate in the week prior to the discount or Lombard rate change. We regress the absolute values of the 2-day abnormal returns on a dummy variable that takes the value of unity if the repo rate did change. The model can be represented by: $A R_{i, t}=\alpha_{i}+\beta_{1}\left(D_{1}\right)+\omega \omega^{i}$ *Indicates significance at a $1 \%$ level, $* *$ at a $5 \%$ level and $* * *$ at a $1 \%$ level.

TABLE 8. Validity of Bundesbank Rate Changes on Domestic Rate Changes

\begin{tabular}{lrr}
\hline Country & $\beta$ & $T$-Statistic \\
\hline Denmark & -0.5649 & -0.9314 \\
France & -0.1565 & -0.3907 \\
Italy & 0.2698 & 0.4528 \\
Netherlands & 0.8242 & 1.4557 \\
Spain & 0.4047 & 1.2987 \\
Switzerland & 0.1599 & 0.2333 \\
UK & -0.2558 & -0.2930 \\
\hline
\end{tabular}

Note: Table 8 tests whether expectations in the response of the bank stocks to changes in their domestic rate was conditioned by changes in either the German discount or Lombard rate in the week prior. We regress the absolute values of the 2-day abnormal returns on a dummy variable that takes the value of unity if German rates did change. The model can be represented by: $A R_{i, t}=\alpha_{i}+\beta_{1}\left(D_{1}\right)+\omega_{i}$. * Indicates significance at a $1 \%$ level, ** at a $5 \%$ level and $* * *$ at a $1 \%$ level. 
TABLE 9. Validity of Domestic Rate Changes on Bundesbank Rate Changes

\begin{tabular}{lcr}
\hline Country & $\beta$ & $T$-Statistic \\
\hline Denmark & 0.0749 & 0.2872 \\
France & -0.1598 & -0.6283 \\
Italy & -0.3548 & -0.2810 \\
Netherlands & 0.0066 & 0.0373 \\
Spain & -0.1368 & -0.7862 \\
Switzerland & 0.0677 & 0.5799 \\
UK & $0.5938^{* *}$ & 2.2506 \\
\hline
\end{tabular}

Note: Table 9 tests whether expectations in the response of the bank stocks to changes in German rates was conditioned by changes in each markets domestic rates in the week prior. We regress the absolute values of the 2-day abnormal returns on a dummy variable that takes the value of unity if the domestic discount rate did change. The model can be represented by: $A R_{i, t}=\alpha_{i}+\beta_{1}\left(D_{1}\right)+\omega^{i}{ }^{*}$ *Indicates significance at a $1 \%$ level, ** at a $5 \%$ level and $* * *$ at a $1 \%$ level.

\section{Concluding Comments}

The results contained in this article make intriguing reading. While much of the empirical analysis makes generlizable findings hard to make, it is apparent that to some degree information flows across Europe do occur with regard to German interest rate changes. In particular, the analysis of individual rate changes shows that not only do non-German banks and equities react to Bundesbank policy, but that the markets appear to differentiate with regard to the importance of rate changes, both in terms of the market concerned and financial institutions and equities in general. The results would therefore support the hypothesis of cross-border information flows and confirm the importance of the Bundesbank in the ERM and in the lead up to monetary union. The findings are confirmed by the fact that in most cases non-German banks have a tendency to react more strongly to German interest rate changes than to domestic rate changes or to other foreign rate changes.

\section{References}

Agrawal, J., and Kamukara, W.A. 1995. The economic worth of celebrity endorsers: An event study analysis. Journal of Marketing 59: 56-62.

Bae, S.C. 1990. Interest rate changes and common stock returns of financial 
intermediaries. Journal of Financial Research 13: 71-79.

Ball, R., and Brown, P. 1968. An empirical evaluation of accounting income numbers. Journal of Accounting Research 6: 159-178.

Beckers, S. 1999. Investment implications of a single European capital market. Journal of Portfolio Management 25: Spring, 9-17.

Boehmer, E.; Musumeci, J.; and Poulsen, A.B. 1991. Event study methodology under conditions of event induced variance. Journal of Financial Economics 30: 253-272.

Born, J.A., and Moser, J.T. 1990. Bank equity returns and changes in the discount rate. Journal of Financial Services Research 5: 223-241.

Bowen, R.; Castanias, R.; and Daley, L. 1983. Intra-industry effects of the accident at Three Mile Island. Journal of Financial and Quantitative Analysis 18: 87-111.

Brown, S., and Warner, J.B. 1980. Measuring security price performance. Journal of Financial Economics 8: 205-258.

Brown, S., and Warner, J.B. 1985. Using daily stock returns: The case of event studies. Journal of Financial Economics 15: 3-31.

Choi, J.J.; Elyasiani, E.; and Kopecky, K.J. 1992. The sensitivity of bank stocks to returns to market, interest and exchange rate risks. Journal of Banking and Finance 16: 983-1004.

Cook, T., and Hahn, T. 1988. The information content of discount rate announcements and their effect on market interest rates. Journal of Money, Credit and Banking 20: 167-180.

Cornell, B., and Shapiro, A. 1986. The reaction of bank stocks to the international debt crisis. Journal of Banking and Finance 10: 55-73.

Dueker, M. 1992. The response of market interest rates to discount rate changes. Federal Reserve Bank of St. Louis Review 74: 78-91.

Drummen, M., and Zimmermann, H. 1992. The structure of European stock returns. Financial Analysts Journal July-August, 15-26.

Eckbo, B.; Makismovic, V.; and Williams, J. 1990. Consistent estimation of cross-section models in event studies. Review of Financial Studies 3: 343365.

Elyasiani, E., and Mansur, I. 1998. Sensitivity of the bank stock returns distribution to changes in the level and volatility of interest rates: A GARCH-M model. Journal of Banking and Finance 22: 535-563.

Engle, R.; Ng, V.; and Rothschild, M. 1990. Asset pricing with a factor-ARCH covariance structure: Empirical estimates for treasury bills. Journal of Econometrics 80: 213-237.

Espita, M., and Santamaria, R. 1994. International diversification among the capital markets of the EEC. Applied Financial Economics 4: 1-10.

Flannary, M.J. 1983. Interest Rates and Bank Profitability: Additional Evidence. Journal of Money, Credit and Banking 15: 435-335.

Flannery, M.J., and James, C.M. 1984. The effect of interest rate changes in the 
common stock returns of financial institutions. Journal of Finance 39: 11411153.

Flannery, M.J.; Hameed, A.S.; and Harjes, R.H. 1997. Asset pricing, time-varying risk premia and interest rate risk. Journal of Banking and Finance 21: 315335.

Fraser, P.; Helliar, C.V.; and Power, D.M. 1994. An empirical investigation of convergence among European equity markets. Applied Financial Economics 4: 149-157.

Hafer, R.W. 1986. The response of stock prices to changes in weekly money and discount rates. Federal Reserve Bank of St. Louis Review 68: 5-14.

Hakkio, C., and Pearce, D. 1992. Discount rate policy under alternative operating regimes: An empirical investigation. International Review of Economics and Finance 1: 55-72.

Kaen, F.R.; Sherman, H.C.; and Tehranian, H. 1997. The effects of Bundesbank Discount and Lombard rate changes on German bank stocks. Journal of Multinational Financial Management 7: 1-25.

Kanas, A. 1998. Volatility spillovers across equity markets: European evidence. Applied Financial Economics 8: 245-256.

Kane, E.J., and Unal, H. 1988. Change in market assessment of deposit institution riskiness. Journal of Financial Services Research 2: 201-229.

Karafiath, I.; Mynatt, R.; and Smith, K.L. 1991. The Brazilian default announcement and the contagion effect hypothesis. Journal of Banking and Finance 15: 699-716.

Kwan, S.H. 1991. Re-examination of interest rate sensitivity of commercial bank stock returns using a random coefficient model. Journal of Financial Services Research 5: 61-76.

Lang, L.H.P., and Stultz, R.M. 1992. Contagion and competitive intra-industry effects of bankruptcy announcements: An empirical analysis. Journal of Financial Economics 32: 45-60.

Lynge, M.J., and Zumwalt, J.K. 1980. An empirical study of the interest rate sensitivity of commercial bank returns: A multi-index approach. Journal of Financial and Quantitative Analysis 15: 731-742.

MacKinlay, C. 1997. Event studies in economics and finance. Journal of Economic Literature 35: 13-39.

Neuberger, J.A. 1994. Interest rate risk at US commercial banks. Federal Reserve Bank of San Francisco working paper.

Pearce, D.K., and Roley, V.V. 1985. Stock prices and economic news. Journal of Business 58: 49-67.

Roley, V.V., and Troll, R. 1984. The impact of discount rate changes on market interest rates. Federal Reserve Bank of Kansas City Economic Review. January: 27-39.

Rouwenhorst, K. G. 1999. European equity markets and EMU. Financial Analysts Journal May-June, 57-64. 
Scott, W.L., and Peterson, R.L. 1986. Interest rate risk and equity values of hedged and unhedged financial intermediaries. Journal of Financial Research 9: 325-329.

Sinclair, C.D.; Power, D.M.; Lonie, A.A.; and Helliar, C.V. 1997. An investigation of the stability of returns in Western European equity markets. European Journal of Finance 3: 87-106.

Smirlock, M., and Yawitz, J. 1985. Asset returns, discount rate changes and market efficiency. Journal of Finance 40: 1141-1158.

Song, F. 1994. A two-factor ARCH model for deposit institution stock returns. Journal of Money, Credit and Banking 26: 323-340.

Stone, B.K. 1974. Systematic interest rate risk in a two-index model of returns. Journal of Financial and Quantitative Analysis 9: 709-721.

Sweeney, R.J., and Warga, A.D. 1986. The pricing of interest rate risk: Evidence from the stock market. Journal of Finance 41: 393-410.

Thornton, D.L. 1982. Discount rate and market interest rates: What's the connection? Federal Reserve Bank of St. Louis Review 64: 3-14.

Waud, R.N. 1970. Public interpretation of Federal Reserve discount rate changes: Evidence on the 'announcement effect'. Econometrica 38: 231-250.

Westmore, J.L., and Brock, J.R. 1994. Commercial bank risk: Market interest rate, foreign exchange. Journal of Financial Research 17: 585-596.

Yourougou, P. 1990. Interest rate risk and the pricing of depository financial intermediary common stock. Journal of Banking and Finance 14: 803-820. 